\title{
EMBRYONAL RHABDOMIOSARCOMA
}

\section{Laporan Sebuah Kasus dengan review literatur}

\author{
$\underline{\text { Herlina Eka Shinta }^{1}}, \underline{\text { Ni Putu Sriwidyani }}{ }^{2}$
}

${ }^{1}$ Staf pengajar Departemen Patologi Anatomi FK UPR Palangkaraya

${ }^{2}$ Staf pengajar, SMF Patologi Anatomi, FK UNUD/RSUP Sanglah Denpasar

\begin{abstract}
ABSTRAK
Embryonal rhabdomiosarcoma (ERMS) adalah suatu keganasan yang berasal dari jaringan lunak dan sering di jumpai pada anak-anak. Insidensinya mendekati 4,5 kasus tiap 1 juta anak-anak dibawah usia 20 tahun. Insidensi tertinggi pada umur rata-rata 6 tahun. Dilaporkan sebuah kasus ERMS regio femur sinistra pada seorang anak lakilaki usia 1 tahun, dengan benjolan pada paha kiri yang dikeluhkan sejak 6 bulan sebelum masuk rumah sakit. Benjolan semakin membesar, tidak disertai nyeri, dan tidak ada riwayat trauma sebelumnya. Pada pemeriksaan fisik ditemukan benjolan 4 x $5 \mathrm{~cm}$ di daerah femur kiri. Pada pemeriksaan histopatologi tampak tumor berbatas tidak tegas dengan didapatkan jaringan ikat disekitar tumor. Tumor seluler terdiri dari sel-sel kecil dengan inti bulat ovoid, kromatin inti hiperkromatik, beberapa sel tumor sedang bermitosis. Tampak daerah yang lebih hiposeluler dengan gambaran pembuluh-pembuluh darah yang membentuk pola hemangio perisitik. Pasien didiagnosis suatu small round cell tumor dengan kecenderungan suatu ERMS. Diagnosis histopatologi dikonfirmasi dengan pulasan imunohistokimia. Pulasan desmin positif pada sebagian sel, MyoD1 positif pada hampir seluruh inti, SMA negatif. CD99 Non spesifik, LCA dan CD20 negatif. Diagnosis ERMS ditegakkan berdasarkan data klinis, radiologis, histopatologis dan ditunjang dengan imunohistokimia.
\end{abstract}

Kata Kunci: Embryonal rhabdomyosarcoma, femur, kasus, review literatur

ABSTRACT

Embryonal rhabdomiosarcoma (ERMS) is a malignancy that originates from soft tissue and is often encountered in children. Its incidence is close to 4.5 cases per 1 million children under the age of 20 years. The highest incidence is at an average age of 6 years. A case of ERMS in the left femur region was reported in a boy aged 1 year, with a lump on the left thigh complained of 6 months before being hospitalized. Lumps get bigger, not accompanied by pain, and there is no history of previous trauma. On physical examination found a $4 \times 5 \mathrm{~cm}$ lump in the left femur area. On histopathological examination, there was an indistinct borderline tumor with connective tissue around the tumor. Cellular tumors consist of small cells with a rounded ovoid nucleus, hyperchromatic chromatin nuclei, some tumor cells are mytosis. Looks a more hypocellular area with a picture of blood vessels that form a perisitic hemangio pattern. The patient was diagnosed with a small round cell tumor with an ERMS tendency. Histopathological diagnosis was confirmed by immunohistochemical staining. Relative desmin is positive in some cells, MyoD1 is positive in almost all cores, negative SMA. Non specific CD99, negative LCA and CD20. The diagnosis of ERMS is based on clinical, radiological, histopathological data and is supported by immunohistochemistry.

Keywords: Embryonal rhabdomyosarcoma, femur, case, literature review 


\section{PENDAHULUAN}

Rabdomiosarkoma (RMS) adalah suatu penyakit keganasan pada jaringan lunak yang terjadi pada otot serat lintang. Merupakan 10\% -15\% dari sarkoma jaringan lunak dan 5\% - 8\% dari semua kasus keganasan pada anak. Sejak Januari 1988 Desember 1992 di bagian Anak RSUD Dr. Sutomo/FK Unair Surabaya ditemukan 2 kasus Rabdomiosarkoma dari 28 kasus tumor abdomen. Sedangkan di Sub bagian Hematologi/Onkologi BIKA FK USU / SRPM Medan sejak Januari 1987Desember 1993 didapatkan 4 kasus Rabdomiosarkoma dari 11 kasus sarkoma tulang dan jaringan lunak. Rabdomiosarkoma dapat terjadi pada semua usia dengan insiden terbanyak pada usia 2 - 6 tahun dan 15 - 19 tahun. Laki - laki dan perempuan dengan perbandingan $1: 1,1 \& 1,5: 1$. Lokasi umumnya terdapat pada kepala dan leher (3-65\%) menyusul anggota gerak (24\%), sistem urogenital (18 $\%)$, badan $(8 \%)$, retropertoneal $(7 \%)$ dan tempat lain $(2-3 \%)^{1}$.

Dua bentuk yang sering terjadi adalah embrional rabdomiosarkoma (70\%) dan alveolar rabdomiosarkoma (20\%), literatur lain menambahkan subtipe pleomorfik ${ }^{1,2,3,4}$. Embrional rabdomiosarkoma (ERMS) merupakan jenis yang paling sering ditemukan pada anak, kira-kira $60 \%$ dari semua kasus rabdomiosarkoma. Pada pemeriksaan histologi jenis ini mempunyai variabilitas histologi yang tinggi, dimana menggambarkan beberapa tingkatan dari morfologis otot skeletal. Dan merupakan neoplasma dengan differensiasi yang tinggi yang terdiri dari rabdomioblas dengan sitoplasma eosinofilik. Desmin dan aktin yang terdapat pada otot digunakan untuk mendiagnosis rabdomiosarkoma ${ }^{5}$.

ERMS mempunyai diferensial diagnosis yang banyak, antara lain neuroblastoma, precursor $\mathrm{T}$ lymphoblastic leukemia, Melanotic Neuroectodermal Tumor of Infancy, desmoplastic small (round) cell tumor, synaptophysin ewing sarcoma. Umur dan lokasi bisa mengarahkan diagnosis, namun diperlukan pemeriksaan imunohistokimia untuk konfirmasi diagnosis ${ }^{6}$.

Tulisan ini melaporkan sebuah kasus pada seorang anak laki-laki, usia 1 tahun dengan diagnosis yang akan ditegakkan dari pemeriksaan $\mathrm{HE}$ dan dikonfirmasi dengan pemeriksaan imunohistokimia disertai tinjauan pustaka.

\section{KASUS}

Pasien adalah seorang anak laki-laki, usia 1 tahun, suku bangsa Bali, datang ke RSUP sanglah dengan keluhan benjolan pada paha kiri selama bulan. Keluhan tersebut tanpa adanya rasa nyeri. Tidak ada riwayat trauma sebelumnya. Riwayat penyakit yang sama pada keluarga juga di sangkal. Pada pemeriksaan didapatkan keadaan umum dan tanda vital pasien dalam batas normal. Pada pemeriksaan fisik ekstremitas bawah, paha kiri didapatkan massa dengan ukuran $4 \times 5 \mathrm{~cm}$, konsistensi kenyal, melekat dengan dasar dan berbatas tegas. Massa tersebut tidak nyeri. Pada permukaan kulit tidak tampak gambaran adanya pelebaran pembuluh darah. Pada pemeriksaan laboratorium dalam batas normal.

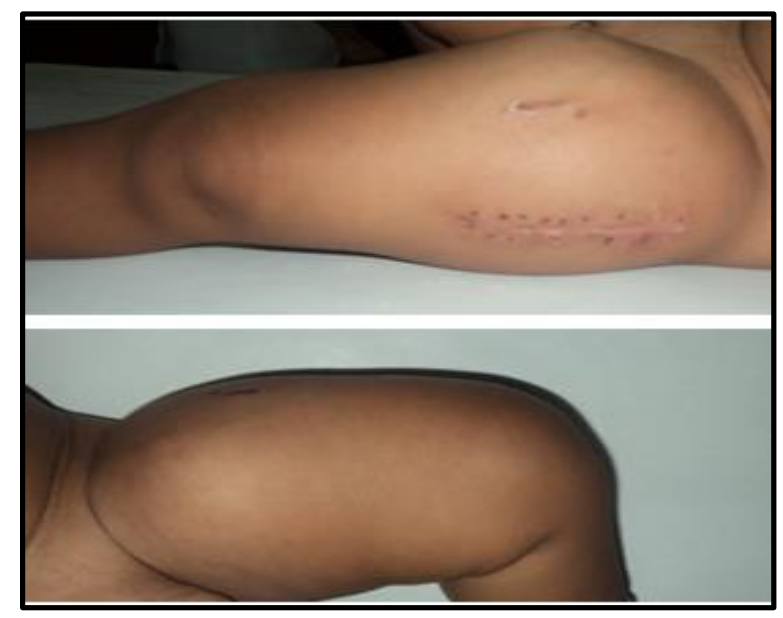

Gambar 1.Paha kiri didapatkan massa tanpa nyeri dan tidak berbatas tegas, ukuran $4 \times 5 \mathrm{~cm}$.

Pada pemeriksaan MRI ditemukan massa di dalam otot vastus intermedius, dengan adanya komponen nekrotik, perdarahan minimal, batas tegas, menekan otot dan jaringan sekitarnya. Dengan kontras tampak enhanced sedang, kecuali di bagian tengah lesi tidak enhanced. Tidak tampak destruksi tulang ataupun tanda osteomyelitis. Kesimpulan sesuai tumor intra muskular, dengan diagnosis banding rhabdomyosarcoma dan myxoma. 


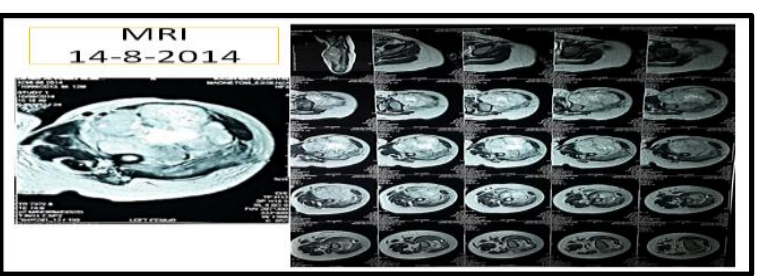

Gambar 2. Tidak tampak adanya destruksi ataupun tanda osteomyelitis.

Berdasarkan hasil anamnesis, pemeriksaan fisik dan penunjang, pasien tersebut di diagnosis sebagai primary malignant soft tissue tumor left femur, dengan diagnosis banding Rhabdomyosarcoma. Kemudian dilakukan pembedahan dan spesimen dikirimkan ke bagian Patologi Anatomi.

Pada pemeriksaan makroskopis didapatkan biopsi tumor dengan ukuran $1 \times 0,5 \times 0,2 \mathrm{~cm}$, warna putih abu-abu. Pada pemeriksaan mikroskopis didapatkan tumor yang tidak berbatas tegas dengan jaringan ikat disekitarnya. Tumor seluler terdiri dari sel-sel kecil dengan inti bulat ovoid, kromatin inti hiperkromatik dan mitosis dapat dijumpai. Pada beberapa area tampak tumor yang lebih hiposeluler. Diantaranya tampak pembuluh-pembuluh darah dengan membentuk pola hemangio perisitik.
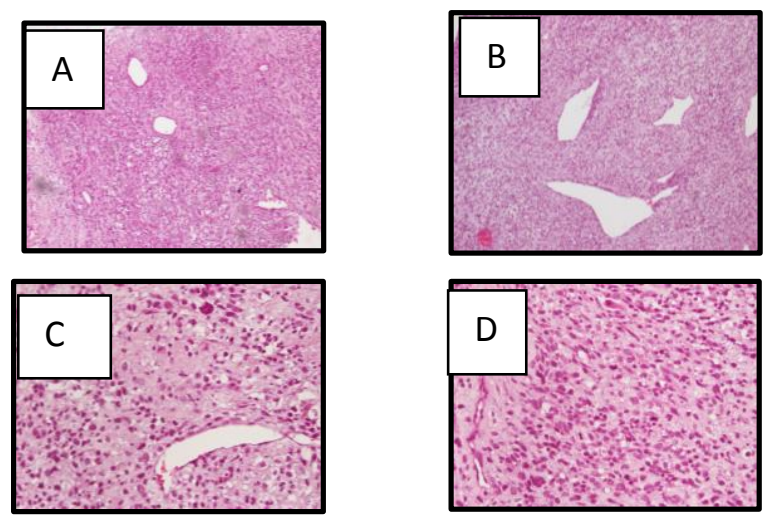

Gambar 3. tumor yang tidak berbatas tegas dengan jaringan sekitarnya. (A) Tampak tumor seluler terdiri dari sel-sel kecil dengan inti bulat ovoid, kromatin inti hiperkromatik.(B) Diantaranya tampak pembuluh-pembuluh darah dengan membentuk pola hemangioperisitik.

(C) Pada beberapa area tampak tumor yang lebih hiposeluler. (D) Sel tumor menunjukkan banyak mitosis.
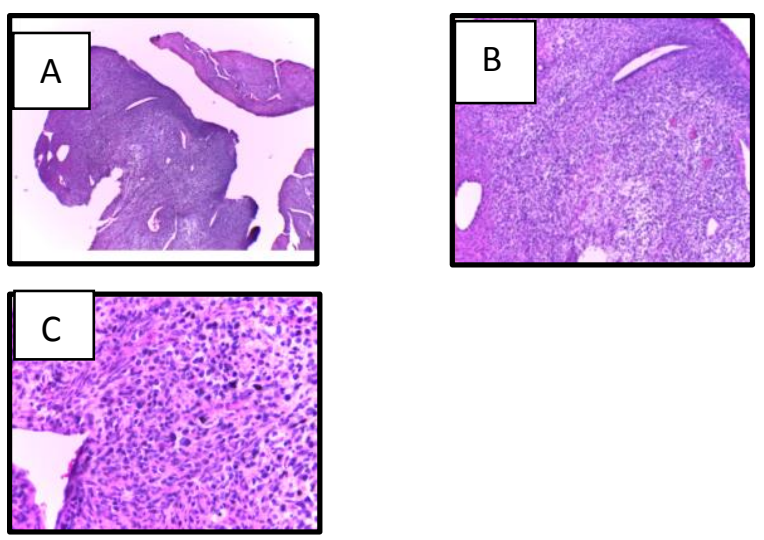

Gambar 4.Pewarnaan dengan HE A.40X, B. 100X, C. $400 \mathrm{X}$

Pada pemeriksaan imunohistokimia didapatkan desmin positif pada sebagian sel, MyoD1 positif pada hampir seluruh inti, SMA negatif. CD99 Non spesifik, LCA dan CD20 negatif .
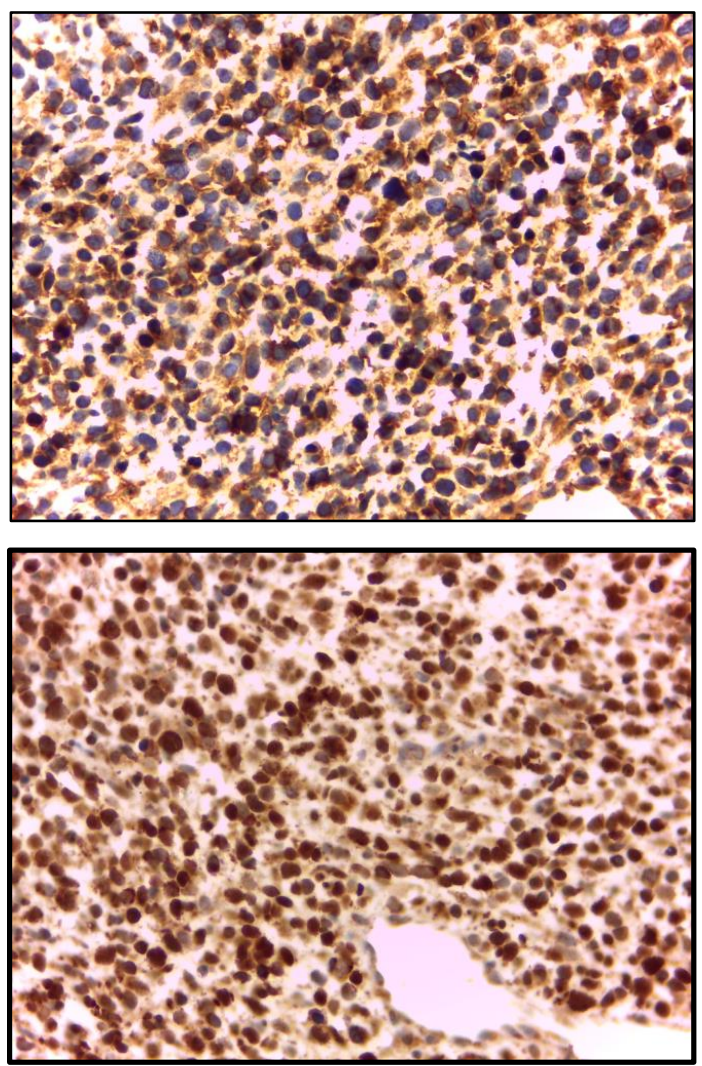

Gambar 5. Hasil CD99 Non spesifik Gambar 6. Hasil MyoD1 positif pada hampir seluruh inti 


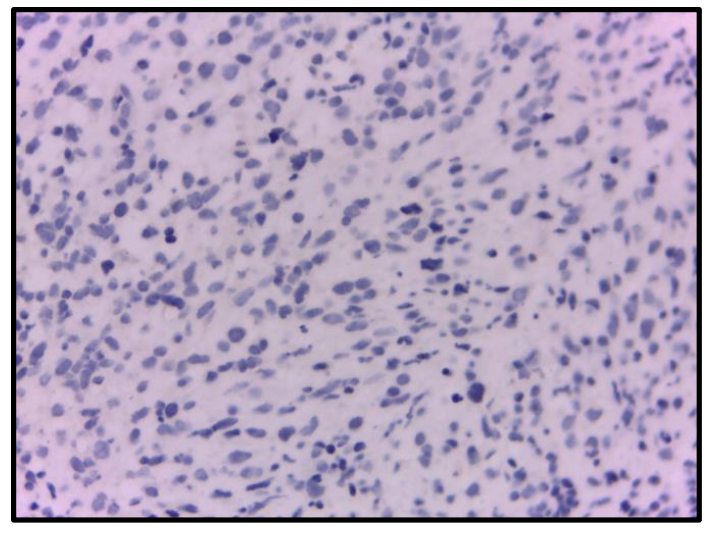

Gambar 7. Hasil CD20 negatif

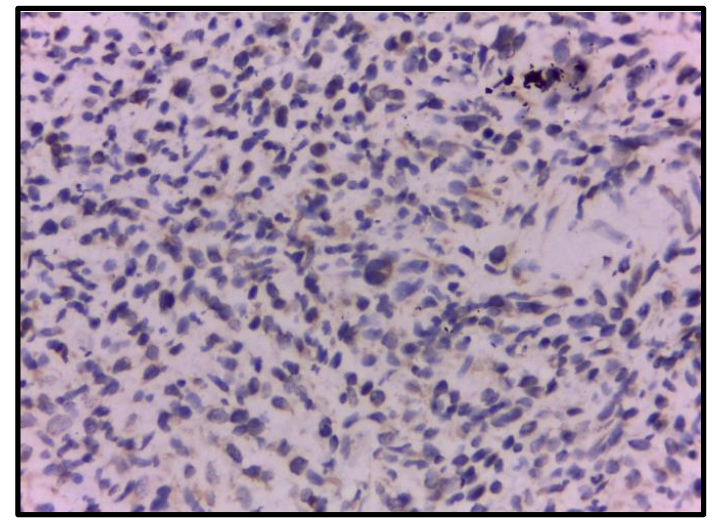

Gambar 8. Hasil Desmin positif pada sebagian sel.

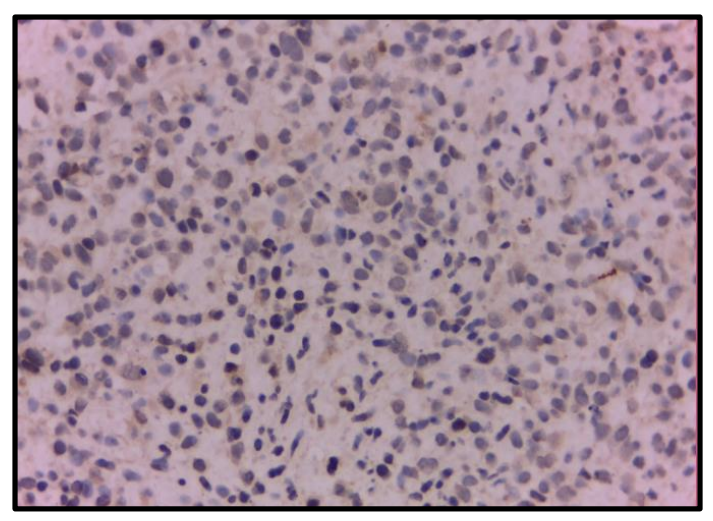

Gambar 15. Hasil LCA negatif

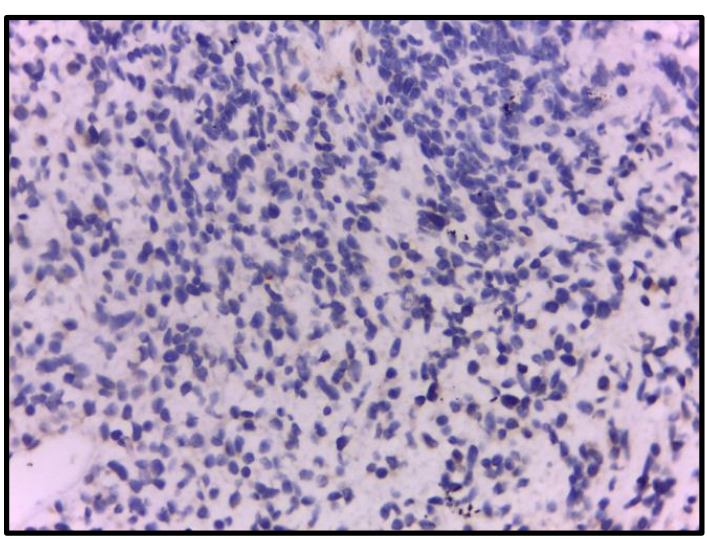

Gambar 9. Hasil SMA (Smooth Muscle Actin) negatif.

\section{DISKUSI}

Embryonal rhabdomyosarcoma (ERMS) sebagian besar terjadi pada laki-laki ( $\mathrm{M}: \mathrm{F}=1,5: 1)$ dan puncak pada kelompok usia 0 sampai 4 tahun pada sekitar 4 kasus per 1 juta anak, dengan insiden yang lebih rendah pada remaja, sekitar 1,5 kasus per 1 juta remaja ${ }^{7}$. Umumnya ERMS mempunyai prognosis yang lebih baik dari alveolar rabdomiosarkoma (ARMS). ARMS sering terdapat pada anggota gerak, badan dan perineum dengan pertumbuhan yang cepat ${ }^{8,9,10,11}$

$\begin{array}{ccc}\text { Kebanyakan } & \text { anak-anak } & \text { dengan } \\ \text { rhabdomysarcoma tidak memiliki } & \text { kondisi }\end{array}$ predisposisi genetik atau faktor resiko(95-98\% kasus), kecuali pada sebagian kecil anak anak-anak dengan sindrom tertentu. ERMS dapat disebabkan oleh adanya sindrom akibat mutasi germline. Dapat pula disebabkan oleh adanya mutasi pada $R A S$ signalling pathway yang disebut Costello syndrome (mutasi gen HRAS), Neurofibromatosis 1 (mutasi gen NF1) dan Noonan syndrome (mutasi pada sebagian gen). Sebagian kecil lainnya dilaporkan berasosiasi dengan sindrom beckwith-wiedemann, yang disebabkan disregulasi gen imprinted pada regio $11 \mathrm{p} 15.5 .{ }^{12}$

Pada ERMS gejala klinis yang ditimbulkan bervariasi, secara umum berhubungan dengan massa dan penyumbatan yang ditimbulkan oleh massa tersebut.Tumor ini jarang memberikan keluhan bila ukurannya kecil. Jenis tumor ini adalah tumor "lunak" tanpa rasa sakit. Penderita mengeluh bila tumor telah membesar dan memberikan tanda-tanda penekanan jaringan sekitar tumor seperti neuralgia, paralisis, iskemia, sedangkan penekanan pada sistem digestif akan mengakibatkan gejala obstruksi ${ }^{13}$. Gambaran yang paling umum terdapat adalah massa yang mungkin nyeri atau mungkin tidak nyeri. Gejala 
disebabkan oleh penggeseran atau obstruksi struktur normal. Rhabdomyosarcoma pada tubuh atau anggota gerak pertama-tama sering diketahui setelah trauma dan mungkin mula-mula dianggap sebagai hematom. Bila pembengkakan itu tidak mereda atau malah bertambah, keganasan harus dicurigai. Tetapi manifestasi gejala yang ditimbulkan sangatlah lambat ${ }^{14}$. Pada kasus ini massa yang timbul di paha kiri sejak 6 bulan tanpa menimbulkan gejala dan rasa nyeri.

Faktor prognosis untuk anak atau remaja dengan rabdomyosarkoma berhubungan dengan usia pasien, situs asal, ukuran tumor (diameter terlebar), resectability, kehadiran metastasis, jumlah situs metastasis atau jaringan yang terlibat, ada atau tidak adanya kelenjar getah bening daerah keterlibatan, subtipe histopatologi (alveolar vs embrional), dan pengiriman terapi radiasi pada kasus tertentu ${ }^{15}$. Rabdomiosarkoma biasanya dapat disembuhkan dalam kebanyakan anak-anak dengan penyakit lokal yang menerima terapi modalitas kombinasi, dengan lebih dari $70 \%$ yang masih hidup 5 tahun setelah diagnosis ${ }^{15,16,17}$.

Pada makroskopis, tumor ERMS berkorelasi dengan lokasi primer dimana tumor dengan ukuran besar biasanya ditemukan pada abdomen dan ekstremitas dengan ukuran melebihi 6$8 \mathrm{~cm}$. Tumor umumnya berupa jaringan gelatinus yang lunak, mengkilat, pada potongan akan terlihat permukaan yang berwarna putih abu-abu dengan atau tanpa area perdarahan maupun nekrosis.Umumnya tumor berbatas tegas dengan tanpa adanya kapsul jaringan.Pada kasus ini gambaran makroskopis berupa jaringan biopsi yang berwarna putih abu-abu dengan konsistensi yang kenyal ${ }^{18}$.

Pada mikroskopis didapatkan sel tumor yang sangat menyerupai berbagai variasi embriogenesis normal otot skelet, tetapi lebih bevariasi, dari gambaran diferensiasi yang buruk yang sulit untuk didiagnosis tanpa dilakukan pemeriksaan imunohistokimia, sampai dengan diferensiasi baik, dengan gambaran menyerupai otot fetal. Gambaran histologi nya umumnya berupa (1) berbagai derajat selularitas dengan kelompok padat, area hiperselular dan gambaran area myxoid yang longgar. (2) gambaran campuran sel-sel dengan orientasi buruk, kecil, undifferentiated, hiperkromatik, bentuk bulat atau berbentuk spindle, dengan jumlah sel diferensiasi yang bervariasi dengan karakteristik sitoplasma eosinofilik yang merupakan karakteristik rhabdomyoblast, dan (3) gambaran matriks yang mengandung sedikit kolagen dan sejumlah material myxoid yang bervariasi. Gambaran cross-striations terlihat pada 50-60\% kasus. Serupa dengan sel otot skelet, ERMS mengandung sel mesenkimal primitif pada berbagai variasi myogenesis, dengan jumlah rhabdomyoblast yang bervariasi ${ }^{18}$.

Rhabdomyoblast ditandai dengan sitoplasma yang eosinofilik dan elongasi, bermanifestasi sebagai sel-sel tadpole, strap dan spider. Pada diferensiasi terminal dapat terlihat sel-sel dengan gambaran eosinofilik terang, dengan inti diperifer dan multinukleasi serta gambaran cross striation pada sitoplasma. Pada ERMS dengan struktur lembaran agregat embrioid dari myoblast longgar, mesenkim myxoid, menyebabkan gambaran yang padat dan bagian dengan selularitas yang longgar. Pada beberapa bagian tampak Pada ERMS yang membentuk struktur lembaran khususnya pada biopsi yang terbatas, ERMS dapat hanya berisi sedikit lembaran yang seluler yang berisi se-sel yang berbentuk bulat. Dapat pula ditemukan sel-sel bizzare,mitosis multipolar ${ }^{18}$. Pada kasus ini didapatkan tumor yang tidak berbatas tegas dengan jaringan sekitarnya, tampak seluler terdiri dari sel-sel kecil dengan inti bulat ovoid, kromatin inti hiperkromatik dan mitosis dapat dijumpai. Pada beberapa area tampak tumor yang lebih hiposeluler, diantaranya tampak pembuluh-pembuluh darah dengan membentuk pola hemangiperisitik. Tidak dijumpai sel yang menunjukkan gambaran morfologi rabdhomyoblast.

Pada kasus ERMS marker-marker muskoloskeletal yang akan diperiksa dengan pemeriksaan imunohistokimia, marker-marker ini berhubungan dengan tingkat diferensiasi tumor. Vimentin pada kebanyakkan sel-sel primitif , akan terwarna pada sitoplasma, desmin dan aktin didapatkan pada rhabdomyoblast. Antibodi MyoD dan myogenin marker yang sangat spesifik dan sensitif untuk rhabdomyosarcomadan berguna untuk diagnosis. Pada ERMS secara tipikal menunjukan hasil yang negatif, bagian fokal yang lemah, atau myogenin dengan gambaran pewarnaan sedang. ERMS dapat menunjukkan suatu pewarnaan yang abberant pada marker keratin, S100 dan neurofilamen. Hasil SMA yang positif merupakan hal yang tidak biasanya ${ }^{19}$. Pada kasus ini didapatkan hasil pemeriksaan imunohistokimia desmin positif pada sebagian sel, MyoD1positif pada hampir seluruh inti, SMA negatif. CD99 Non spesifik, LCA dan CD20 negatif .

Pada diagnosis ERMS, sangat penting untuk dapat memikirkan dan menyingkirkan adanya keganasan lain. Diferensial diagnosis dari ERMS adalah ewing sarcoma-primitive neuroectodermal tumor (ES-PNET), neuroblastoma, wilm tumor dan Limfoma maligna Dimana akan menunjukkan gambaran histologis yang mirip satu sama lain dengan karakteristik atypical round cell yang uniform dan biasanya dibedakan dengan menggunakan, 
dimana ES-PNET, neuroblastoma, wilm tumor dan Limfoma maligna akan memberikan hasil myogenin, myoD1 dan desmin yang negatif ${ }^{6}$.

Ewing sarcoma-primitive neuroectodermal tumor (ES-PNET), merupakan small round cell neuroectodermal tumor primitive dengan diferensiasi neural, dengan insidensi masa anak-anak dan emaja, dengan puncak kejadian tertinggi pada usia 18 tahun. Dngan morfologi tumor terdiri dari sel bulat kecil yang seragam, inti bulat, kromatin halus, sitoplasma jernih atau eosinofilik, dengan membran sitoplasma yang tidak jelas. Dapat ditemukan gambaran Homerwright rosettes. Pada pemeriksaan imunohistokimia CD99 terekspresi positif pada hampir semua kasus, meskipun tidak spesifik.Ekspresi positif juga ditemukan pada vimentin.

Neuroblastoma, merupakan tumor ganas neuroektodermal, yang terjadi antara usia 2 sampai 90 tahun, atau pada dekade ke-2 dan 6. Morfologi sel-sel neoplastik dengan inti bulat kecil yang seragam dengan sitoplasma sempit dan tersebar membentuk gambaran salt and pepper, inti dengan kromatin kasar dan anak inti yang menonjol. Dapat ditemukan gambaran Homer Wrigth rosettes (pseudorosettes) dan Flexner-Wintersteiner rosette (true neural rosette) dapat ditemukan. Pada pemeriksaan imunohistokimia memberikan hasil positif untuk synaptophysin, CD56, chromogranin, S100 , vimentin dan cytokeratin.

Malignant lymphoma adalah neoplasma sel limfoid yang tersusun difus di antara stroma jaringan ikat dengan s el-sel berbentuk bulat bisa berukuran kecil dan besar ( 2-4 kali sel limfosit matur) atau kombinasi. Inti bulat kecil

Pemeriksaan imunuhistokimia pada ERMS adalah pemeriksaaan untuk marker otot skelet. Menunjukan pewarnaan yang kuat pada antigen myogen, khususnya untuk sel yang menunjukkan diferensiasi myoblastik, demikian pula untuk desmin dan aktin akan memberikan hasil yang positif pada ERMS. Desmin dan aktin yang terdapat pada otot digunakan untuk mendiagnosis rabdomiosarkoma. Desmin adalah protein filament menengah yang terdapat dalam sel otot polos, sel otot lurik dan miokard, pada pemeriksaan imunohistokimia (IHK) pada pasien ini didapatkan desmin positif pada sebagian sel yang menandakan bahwa sel tersebut mengandung sel otot polos dan lurik. Pada pemeriksaan MyoD1 didapatkan positif pada hampir seluruh inti sel, myoD1 merupakan faktor transkripsi primitif yang mengatur produksi desmin. Sehingga dapat disimpulkan hasil pemeriksaan IHK adalah menunjang diagnosis embrional rabdomiosarkoma ${ }^{19}$.

\section{SIMPULAN}

Pada kasus ERMS femur seorang anak lakilaki usia 1 tahun, diagnosis ditegakkan selain dengan pemeriksaan klinis diperlukan pemeriksaan histopatologi, pencitraan, dan dikonfirmasi dengan pemeriksaan imunohistokimia untuk membedakan dengan kasus lainnya.

\section{DAFTAR PUSTAKA}

1. Michael Walta Dan Stepen H. Thomas. Referat Nyeri Kanker dan tumor.World Journal of Medical Sciences 3 (2): 54-59, 2008 - ISSN 1817-3055 SKYDRUGZ:

Refarat Nyeri Kanker dan Tumor http://skydrugz.blogspot.com/2012/03/refara t-nyeri-kanker-dantumor.

2. Timothy PC. Rhabdomyosarcoma. http://www.emedicine.com

3. Cormier JN, Pollock RE. Soft tissue Sarcoma. In: Brunicardi FC, Andersen DK, Billiar TR, Dunn DL, Hunter JG, Pollock RE, editors. Schwartz Manual of Surgery.

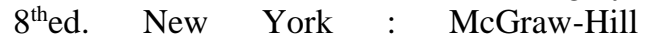
Companies;2006.

4. Wood WC. Soft Tissue Tumors. In: Butcher I.editor. Oxford Textbook of Surgery $2^{\text {nd }} \mathrm{ed}$. Oxford: Oxford University Press:2002.

5. NCI. Childhood Rhabdomiosarcoma Treatment. 2013.

http://www.cancer.gov/cancertopics/pdq/trea tment/childrahabdomiosarcoma/patient

6. Stanford School of Medicine. Surgical Pathology Criteria. 2013. Diseases and Disorders by Sites. http:/surgpathcriteria.edu.

7. Ognjanovic S, Linabery AM, Charbonneau $\mathrm{B}$, et al.: Trends in childhood rhabdomyosarcoma incidence and survival in the United States, 1975-2005. Cancer 115 (18): 4218-26, 2009.

8. Freeman, AI, Woods GM. Genitourinary Tumor. In: Ascraft KW. Pediatric Urology. WB Saunders Company. Philadelphia.1990;449-59.

9. Raney RB, et al. Rhabdomiosarcoma and the undifferentiated sarcoma. In:Pizzo PA and Poplock DG. Pediatric Oncology. JB Lipincolcott Company, Philadelphia.1989;635-58

10. Festa R. Soft tissue Sarcomas. In: Lanzzkonky p. Pediatric Oncology A tretise for the clinician. Mc Graw-Hill Book Company, New York.1983;267-92.

11. Jones PG, Campbell PE. Tumors of infancy an Childhood. Blackwell scientific 
Publications Oxford London. Edinburgh Melbourne.1976;777-95.

12. Anderson J, et al. Disruption of Imprinted Genes at Chromosome Region 11p15.5 in Paediatric Rhabdomyosarcoma.

Neoplasia.1999; Vol 1. No 4.340-48.

13. Wexler L, Helman L. Rhabdomyosarcoma and the undifferentiated sarcomas. In: Pizzo P, Poplack D eds. Principles and Practice of Pediatric Oncology. Philadelphia, Lippincott Raven Publishers, 1997; 799-829.

14. Ferguson MO. Pathology: Rhabdomyosarcoma. http://www.emedicine.com.

15. Crist W, Gehan EA, Ragab AH, et al.: The Third Intergroup Rhabdomyosarcoma Study. J ClinOncol 13 (3): 610-30, 1995.

16. Maurer HM, Gehan EA, Beltangady M, et al.: The Intergroup Rhabdomyosarcoma Study-II. Cancer 71 (5): 1904-22, 1993.

17. Crist WM, Anderson JR, Meza JL, et al.: Intergroup rhabdomyosarcoma study-IV: results for patients with nonmetastatic disease. J ClinOncol 19 (12): 3091-102, 2001

18. Parham DM. The Molecular Biology of Childhood Rhabdomyosarcoma. Semin Diagn Pathol.1994;11;(1);39-46.

19. Sebire NJ, Malone M. Myogenin and Myo D1 Expression in Paediatric Rhabdomyosarcomas. J.Clin Pathol:2003;56:412-16. 